Published by LPMP Imperium

Journal homepage: https:/ / ejournal.imperiuminstitute.org/ index.php/JMSAB

\title{
Menguji Dampak Latar Belakang Pendidikan Pada Intensi Kewirausahaan Mahasiswa Menggunakan Theory of Planned Behavior
}

\section{Andi Syaputra}

Sekolah Tinggi Teknologi Kedirgantaraan,

Yogyakarta, Indonesia

\begin{abstract}
By taking a Theory of Planned Behavior (TPB), this study examines the relationship between students' entrepreneurial, attitude (AT), subjective norms (SN), and perceived behavior control (PBC). The data used in the analysis is from 150 graduate students from 12 universities in Yogyakarta. The results indicate that attitudes and perceived behavior control significantly influenced students' entrepreneurial intentions, but not subjective norms. This study helps understand the role of a qualified educational background, namely the Master of Management in shaping entrepreneurial intentions. Finally, this study reveals the importance of examining students' entrepreneurialism in today's digital age.
\end{abstract}

\section{Keywords:}

Entrepreneurial Intention, Theory of Planned Behavior, Entrepreneurial Role Model, Entrepreneurship.

\section{Corresponding Author:}

Andi Syaputra, Sekolah Tinggi Teknologi Kedirgantaraan,

Yogyakarta, Indonesia

Email: andi.syaputra@sttkd.ac.id

(c) The Author(s) 2021

DOI: https:/ / doi.org/ 10.36407/jmsab.v4i1.275

\section{(c) (1)}

CC BY: This license allows reusers to distribute, remix, adapt, and build upon the material in any medium or format, so long as attribution is given to the creator. The license allows for commercial use.

JMSAB

Research Paper
Management

Received: 25 Sep 2020

Revised: 20 Dec 2020

Accepted: 05 Jan 2021

Online: 13 Feb 2021

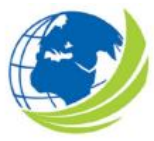

Jurnal Manajemen Strategi dan Aplikasi Bisnis, Vol 4, No. 1, 2021, pp. 43 - 52

eISSN 2655-237X 


\section{PENDAHULUAN}

Indonesia merupakan negara dengan sumber daya yang melimpah. Berbagai sumber daya yang ada telah banyak dimanfaatkan oleh tangan-tangan kreatif yang kemudian berkembang menjadi peluang bisnis. Namun demikian, pengangguran masih menjadi masalah klasik. Para pemuda masih kurang berminat menekuni profesi wirausaha dan memanfaatkan sumber daya. Hal ini dikarenakan pandangan negatif masyarakat terhadap wirausaha. Kebanyakan orang menilai wirausaha sebagai pekerjaan yang kurang terhormat, sumber penghasilan yang tidak stabil dan lain sebagainya. Pandangan seperti ini juga dianut sebagian orang tua yang tidak menginginkan anaknya berwirausaha, melainkan bekerja di perusahaan atau bekerja dilembaga pemerintah sehingga para anak muda tidak tertarik dengan dunia wirausaha melainkan lebih tertarik menjadi seorang pekerja pada perusahaan-perusahaan besar maupun instansi pemerintah untuk menjamin masa depan mereka. Akibatnya banyak lulusan-lulusan perguruan tinggi yang mindset-nya demikian masih menjadi pengangguran. Untuk itu, mendorong kewirausahaan dipandang sebagai solusi potensial bagi para generasi muda yang kesulitan dalam mencari pekerjaan (Aloulou, 2016).

Di era ekonomi pengetahuan, meningkatkan kewirausahaan dan meningkatkan sistem inovasi domestik adalah kunci untuk mempromosikan produktivitas, daya saing, dan pertumbuhan ekonomi suatu negara (Chen et al., 2010). Evaluasi mengenai dampak pendidikan kewirausahaan sangat dibutuhkan (Mohamad et al., 2015). Oleh karena itu, pengalaman wirausaha telah banyak diterapkan pada kurikulum perkuliahan, dengan harapan dapat memberikan efek yang baik terhadap keinginan dalam berwirausaha.

Menumbuhkan dan mempersiapkan mahasiswa untuk terjun ke dunia kewirausahaan merupakan salah satu cara dalam mengurangi pengangguran. Tindakan mereka dalam membuka lapangan pekerjaan baru diharapkan dapat menyerap tenaga kerja di masyarakat. Oleh karena itu studi mengenai intensi berwirausaha mahasiswa menjadi sangat penting. Pengalaman berwirausaha telah banyak diterapkan di beberapa sekolah bisnis, yang diharapankan dapat mempengaruhi niat kewirausahaan. Mahasiswa dengan latar belakang pendidikan Magister Manajemen (MM) dengan pengetahuan bisnis yang lebih baik mempunyai beragam preferensi dalam bekerja termasuk didalamnya berwirausaha. Mengingat efek positif dari kewirausahaan ini, banyak negara-negara berkembang telah meneliti kewirausahaan sebagai solusi mendasar dalam mengurangi angka pengangguran, terutama dikalangan mahasiswa tingkat akhir (Karimi et al., 2014). Mahasiswa disiapkan untuk mandiri dan berfikir kreatif. Oleh karena itu penelitian tentang kewirausahaan menjadi penting guna mencari formula yang sesuai seiring era yang terus berkembang dengan pesat. Beberapa peneliti menyarankan suatu model yang signifikan dalam memperbaiki pemahaman aktivitas-aktivitas kewirausahaan dan intensi berwirausaha mahasiswa, yaitu dengan menggunakan Theory of Planned Behavior (Al-Jubari, 2019; Aloulou, 2016; Krueger et al., 2000; Politis et al., 2016; M. Z. Solesvik, 2013).

Berdasarkan beberapa penelitian terdahulu yang telah menggunakan TPB sebagai prediktor dalam memeriksa intensi berwirausaha mahasiswa, diperoleh hasil yang cukup signifikan. Penggunaan TPB dengan melibatkan variabel pengetahuan kewirausahaan menunjukan bahwa pengetahuan berwirausaha berpengaruh tidak langsung melalui kedua variabel TPB, yaitu sikap dan persepsi pengendalian perilaku (Yaghoubi Farani et al., 2017). Penelitian serupa yang juga melibatkan elemen pendidikan menjadikan ketiga komponen TPB mempengaruhi intensi berwirausaha mahasiswa (Sun et al., 2017). Penelitian lainnya menemukan sikap dan pengendalian perilaku mempengaruhi intensi 
berwirausaha, namun sangat rendah pengaruhnya pada norma sosial. Selain itu, ditemukan juga bahwa terdapat perbedaan intensi berwirausaha dalam lintas negara. Hal ini ditunjukan dari intensi berwirausaha mahasiswa asal Spanyol yang lebih rendah dibandingkan dengan mahasiswa asal Belanda, Jerman, dan Polandia (Gorgievski et al., 2018), sehingga hal tersebut memerlukan penelitian lebih lanjut di Indonesia. Dari beberapa penelitian terdahulu terlihat bahwa latar belakang pendidikan sebagai pengalaman dalam menentukan karir berwirausaha, menentukan tinggi rendahnya intensi berwirausaha mahasiswa. Mahasiswa dengan latar belakang pendidikan magister manajemen dengan tingkatan ilmu yang matang diharapkan memiliki intensi berwirausaha yang tinggi. Sehingga, dengan menggunakan TPB penelitian ini bertujuan untuk memeriksa perilaku terkait intensi berwirausaha mahasiswa Magister Manajemen (MM) dalam mengambil keputusan sebagai wirausahawan dimasa mendatang.

\section{KAJIAN PUSTAKA}

\section{Theory of Planned Behavior}

Dalam upaya untuk mengetahui intensi dari setiap individu diperlukan pemahaman dari individu itu sendiri. Salah satunya dengan menggunakan teori yang banyak digunakan yaitu Theory of Reasoned Action yang kemudian dikembangkan lebih lanjut menjadi Theory of Planned Behavior (Ajzen, 1985). Ditujukan untuk memprediksi perilaku individu secara spesifik. Teori ini menjelaskan faktor utama yang menentukan intensi individu dalam memutuskan suatu perilaku yang spesifik. Intensi di tentukan oleh 3 (tiga) faktor yaitu sikap (attitude), norma subjektif (subjective norms), dan persepsi control prilaku (perceived behavioral control).

\section{$\mathrm{H}_{1}$ : Sikap mahasiswa berpengaruh positif pada intensi berwirausaha}

\section{Wirausaha dan Intensi Berwirausaha}

Secara ekplisit istilah wirausaha (entrepreneur) adalah proses membeli, membawa, dan menyimpan persediaan pembelian yang dilakukan individu dengan tujuan untuk menjual kembali baik grosir atau eceran dengan harga pasti (Hamilton \& Harper, 1994). Meskipun tidak banyak penelitian empiris yang memeriksa bagaimana berbagai jenis pengalaman mempengaruhi niat kewirausahaan (Quan, 2012), namun pengetahuan sebelumnya tentang pasar, masalah pelanggan, dan pengetahuan tentang bagaimana melayani pasar akan mempengaruhi penemuan individu atas peluang, sehingga mempengaruhi perilaku kewirausahaan (Shane, 2000).

Pengalaman wirausaha adalah keterlibatan terdahulu dalam mendirikan bisnis, serta dapat memberikan manfaat positif yaitu dapat mengidentifikasi lebih banyak peluang kewirausahaan (Toft-Kehler et al., 2014). Pengusaha jenis ini mungkin dapat merespon tantangan lebih cepat karena mempunyai pemahaman yang lebih baik dari pengusaha pemula dalam mengumpulkan dan menggunakan informasi (Kotha \& George, 2012). Manfaat lain dari pengalaman terdahulu ialah memotivasi kesadaran wirausahawan tentang apa yang dibutuhkan untuk membangun usaha baru untuk mengejar sebuah bisnis dengan sukses (Toft-Kehler et al., 2014). Dengan adanya pengalaman terdahulu yang relevan dengan bisnis wirausahawan cenderung lebih menyadari sumber daya yang dibutuhkan. Oleh karena itu lulusan dari magister manajemen diharapkan dapat mewakili subjek yang dimaksudkan. 
Individu yang mempunyai keinginan untuk meluncurkan usaha yang baru dikombinasikan dengan beberapa kecenderungan untuk bertindak atas peluang dan kemudian dipicu oleh sebuah perpindahan. Persepsi yang memuaskan tentang variabel kognitif cenderung meningkatkan intensitas niat untuk memulai (Krueger et al., 2000; Yukongdi \& Lopa, 2017) yang disebut sebagai pendorong motivasi (Ajzen, 1991; Yukongdi \& Lopa, 2017). Oleh karena itu, intensi berwirausaha mencerminkan usaha individu dan kesiapan untuk menerapkan perilaku kewirausahaan (Liñán \& Rodríguez-Cohard, 2015).

$\mathrm{H}_{2}$ : Norma subjektif mahasiswa berpengaruh positif pada intensi berwirausaha.

\section{TPB dan Intensi Berwirausaha}

Sikap terhadap perilaku ditentukan oleh keyakinan (belief) tentang bagaimana konsekuensi dari sebuah perilaku, yang disebut sebagai behavioral beliefs (Fishbein \& Ajzen, 2011). Sikap seorang individu terhadap perilaku tertentu diperoleh dari keyakinannya terhadap konsekuensi yang akan diterima ketika menunjukkan perilaku-perilaku tertentu. Ketika individu yakin bahwa perilakunya akan menghasilkan outcome yang positif, maka individu tersebut akan mempunyai sikap positif, begitu juga sebaliknya. Ketika individu yakin bahwa mendirikan sebuah bisnis mampu menghasilkan outcome positif, maka terciptalah sikap positif wirausahawan terhadap semua proses untuk memulai sebuah bisnis atau wirausaha. Sebaliknya ketika seorang individu yakin bahwa perilaku memulai sebuah bisnis atau wirausaha akan menghasilkan outcome negatif, maka wirausahwan akan mempunyai sikap yang negatif terhadap semua proses bisnis atau wirausaha.

Norma subjektif menjadi faktor penentu kedua, hal ini dikarenakan norma sosial merupakan tekanan sosial yang dirasakan oleh individu untuk melakukan atau tidak melakukan suatu perilaku (Fishbein \& Ajzen, 2011). Lebih lanjut dikatakan bahwa norma subjektif dilihat dari adanya normatif belief dan motivation to comply. Normatif belief adalah berbagai aktivitas yang berasal dari referent atau orang dan kelompok yang berpengaruh untuk individu (significant others). Sedangkan segala sesuatu yang berkaitan dengan bagaimana individu ingin mengikuti harapan dari orang atau kelompok yang berpengaruh disebut motivation to comply. Ketika individu yang ingin memulai bisnis atau wirausaha baru mendapat tekanan sosial dari orang atau kelompok yang berpengaruh, maka individu tersebut akan mempunyai keinginan untuk mengikuti harapan-harapan dari orang atau kelompok tersebut sehingga bisa dikatakan ia memiliki intensi yang kuat untuk melakukan perilaku tersebut. Persepsi pengendalian perilaku menjadi faktor penentu intensi yang ketiga.

Persepsi pengendalian perilaku memberikan sumbangan yang signifikan terhadap intensi dalam memulai bisnis pada kalangan pelajar (Yaghoubi Farani et al., 2017). Persepsi pengendalian perilaku merupakan faktor penentu yang kuat terhadap intensi wirausaha dibanding kedua faktor lainnya (Henley et al., 2017). Persepsi pengendalian perilaku adalah pemahaman individu terhadap kendali yang dimilikinya sehubungan dengan perilaku tertentu. Kontrol yang dimiliki individu dapat berupa ketrampilan, ketersediaan sumber daya atau bahkan kesempatan untuk menunjukkan perilaku tertentu. Ketika seseorang percaya bahwa ia mempunyai sumber daya yang cukup, keterampilan, ataupun kesempatan untuk menjadi pengusaha, maka ia akan memiliki intensi yang kuat untuk menunjukkan perilaku tersebut. Penulis juga mengharapkan ketiga komponen dari Theory of Planned Behavior mempunyai hubungan langsung positif dengan intensi wirausaha. Sebagian besar studi yang dilakukan menemukan bahwa komponen dari TPB berkontribusi secara signifikan dalam 


\section{Andi Syaputra}

Theory of Planned Behavior, Entrepreneurial Role Model

menjelaskan intensi berwirausaha (Aloulou, 2016; Henley et al., 2017; Politis et al., 2016; M. Solesvik et al., 2014; Sun et al., 2017). Adapun kekuatan prediksi dari ketiga komponen TPB bervariasi dari satu penelitian ke penelitian yang lain. Terdapat pengaruh SN yang tidak jelas dibeberapa penelitian (Karimi et al., 2014; Yaghoubi Farani et al., 2017). Berdasarkan dari teori dan berbagai temuan terdahulu maka diperoleh hipotesis sebagai berikut:

$\mathrm{H}_{3}$ : Persepsi pengendalian perilaku mahasiswa berpengaruh positif pada intensi berwirausaha

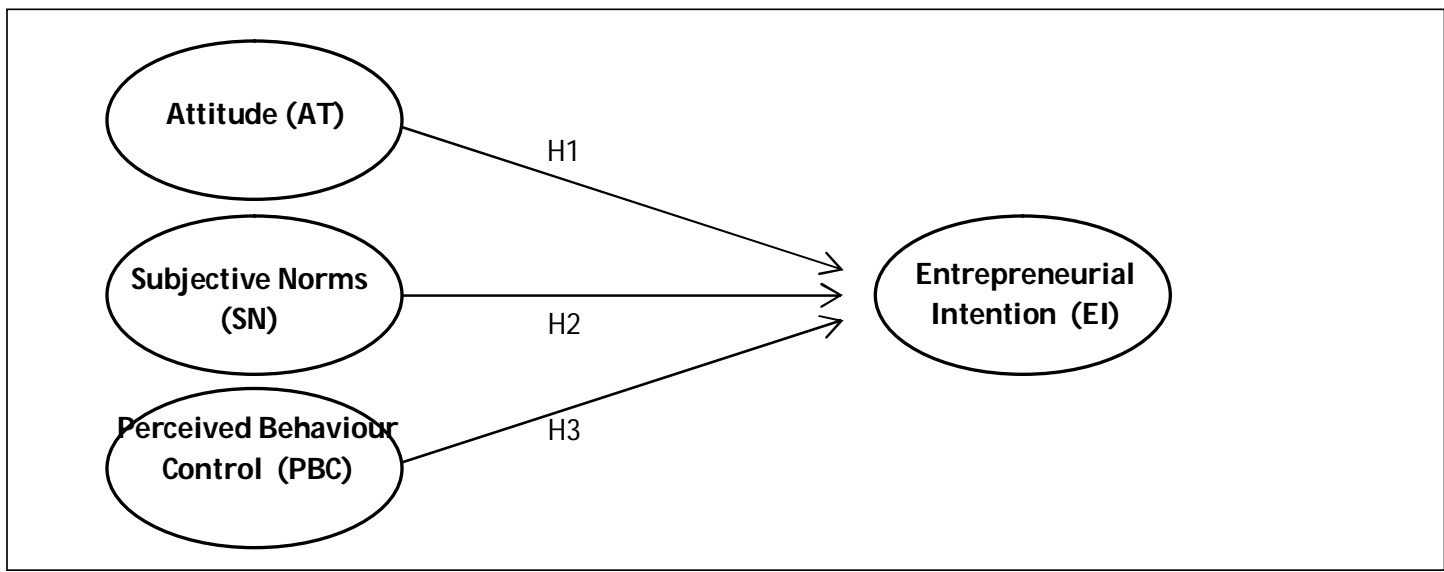

\section{Gambar 1.}

Model Penelitian

\section{METODE PENELITIAN}

Dalam studi ini pengambilan sampel menggunakan metode survei kuisioner dengan teknik probability sampling melalui pendekatan convenience sampling. Teknik pengambilan sampel seperti ini sering digunakan dalam penelitian terdahulu mengenai kewirausahaan (de Jorge Moreno, Laborda Castillo, \& Sanz Triguero, 2012). Jumlah sampel yang di uji sebanyak 150 sampel dengan mengacu kepada kelayakan jumlah sampel menurut Sekaran, U., \& Bougie (2015)

Sampel diambil dari populasi mahasiswa dengan level magister manajemen pada 12 universitas di Yogyakarta. Untuk kebutuhan analisis digunakan skala likert 1 hingga 5 dengan skor 5 untuk respon "sangat setuju" dan 1 untuk respon "sangat tidak setuju". Kemudian analisis statistik dibantu program software IBM SPSS 25 . Untuk memastikan validitas dari indikator-indikator pada variabel penelitian, dilakukan pengujian validitas dengan Exploratory Factor Analysis (EVA). Hasil dari uji EVA dalam Tabel 1 terlihat bersih dan berkelompok sesuai dimensi, tidak ada nilai factor loadings yang menempati 2 kolom (cross loadings), artinya indikator yang ada cukup jelas dan dipahami dengan baik oleh responden. 
Tabel. 1.

Exploratory Factor Analysis

\begin{tabular}{|c|c|c|c|c|}
\hline & \multicolumn{4}{|c|}{ Component } \\
\hline & 1 & 2 & 3 & 4 \\
\hline Attitude 5 & .790 & & & \\
\hline Attitude 4 & .763 & & & \\
\hline Attitude 2 & .756 & & & \\
\hline Attitude 1 & .717 & & & \\
\hline Attitude 3 & .437 & & & \\
\hline Subjective Norms 2 & & .909 & & \\
\hline Subjective Norms 3 & & .796 & & \\
\hline Subjective Norms 5 & & .747 & & \\
\hline Subjective Norms 1 & & .721 & & \\
\hline Subjective Norms 4 & & .560 & & \\
\hline Perceived Behavioral Control 1 & & & .899 & \\
\hline Perceived Behavioral Control 3 & & & .816 & \\
\hline Perceived Behavioral Control 2 & & & .775 & \\
\hline Entrepreneurial Intention 3 & & & & .832 \\
\hline Entrepreneurial Intention 2 & & & & .821 \\
\hline Entrepreneurial Intention 1 & & & & .715 \\
\hline
\end{tabular}

Dalam analisis deskriptif terdapat penilaian yang dimuat dalam bentuk indeks rata-rata, nilai means dengan rentang skala setiap indikatornya dikatakan baik jika berada di 3.40 - 4.19. dalam Tabel 2, dapat dilihat nilai rata-rata dari setiap variabel dalam keadaan baik, yang artinya tanggapan dari responden baik pada setiap variabelnya.

Tabel 2.

Means, Standar Deviasi, Reliable, dan Normalitas

\begin{tabular}{lccll}
\hline Variabel & Mean & SD & $\begin{array}{l}\text { Reliable } \\
\alpha=>0.70\end{array}$ & $\begin{array}{c}\text { Normalitas } \\
\boldsymbol{S}-\mathbf{0}: \sqrt{\mathbf{6} / \boldsymbol{N}}\end{array}$ \\
\hline Sikap & & & & \\
Norma Subjektif & 4.08 & 0.678 & 0.773 & 0.60 \\
Persepsi Pengendalian Perilaku & 4.11 & 0.691 & 0.711 & 1.42 \\
& 3.61 & 0.873 & 0.908 & 1.87 \\
\hline
\end{tabular}

Suatu kuesioner dikatakan handal atau reliable jika jawaban seseorang terhadap pertanyaan konsisten atau stabil dari waktu ke waktu (Ghozali, 2013). Uji reliabilitas dilakukan dengan uji statistik cronbach alpha $(\alpha)$. jika nilai koefisien alpha > 0.70 maka disimpulkan bahwa instrumen penelitian tersebut handal atau reliable. Normalitas dilakukan untuk mengetahui apakah dalam uji regresi antara variabel independen dan dependen mempunyai distribusi normal. Jika dilihat dari hasil persamaan yang menghitung nilai skewness dengan 
Andi Syaputra

Theory of Planned Behavior, Entrepreneurial Role Model

membandingkan nilai kritis yaitu untuk alpha 0,05 nilai kritisnya $<1,96$ maka dapat disimpulkan dalam Tabel 2, ketiga komponen TPB berdistribusi secara normal.

\section{HASIL DAN PEMBAHASAN}

\section{Analisis Regresi}

Analisis regresi dilakukan untuk mengukur kekuatan hubungan antara ketiga variabel komponen dari Theory Planned of Behavior (TPB) terhadap intensi berwirausaha mahasiswa MM. Dalam hal ini variabel sikap, norma subjektif, dan persepsi control perilaku adalah variabel independen. Sedangkan variabel intensi berwirausaha adalah variabel dependen. Dari ringkasan di Tabel 2 besarnya koefisien determinasi (R2) adalah 0,450 hal ini berarti 45,0\% intensi berwirausaha mahasiswa MM yang dapat di jelaskan oleh variasi dari ketiga variabel TPB yaitu sikap, norma sujektif, dan persepsi pengendalian perilaku. Sedangkan $55,0 \%$ dijelaskan oleh sebab-sebab yang lain diluar model. nilai probabilitas $F=0,00$ yang jauh lebih kecil dari $(\mathrm{p}<0,05)$ maka model regresi TPB dapat digunakan untuk memprediksi intensi berwirausaha. Nilai signifikansi $(\mathrm{t})$ sebesar 0,00 untuk variabel sikap yang berarti sesuai ketentuan bahwa nilai tersebut lebih kecil dari $0,05 \quad(p<0,05)$ artinya terdapat hubungan yang positif antara sikap dengan intensi berwirausaha. Sedangkan nilai signifikansi sebesar 0,11 . Untuk pengujian variabel norma subjektif terhadap intensi berwirausaha dengan nilai $0,14(\mathrm{p}>0,05)$ sehingga $(\mathrm{H} 2)$ ditolak dan dapat dinyatakan tidak ada pengaruh signifikan antara norma subjektif dengan intensi berwirausaha. Pengujian ketiga diperoleh nilai signifikansi sebesar $0,00(\mathrm{p}<0.05)$. Artinya pengujian komponen ketiga dari TPB yaitu persepsi pengendalian perilaku berpengaruh positif dan signifikan dalam menjelaskan intensi berwirausaha.

\section{Tabel 3.}

Analisis Regresi

\begin{tabular}{lccccc}
\hline \multicolumn{1}{c}{ Prediktor } & $\mathrm{B}$ & $\mathrm{R}^{2}$ & $\mathrm{~F}$ & $\mathrm{t}$ & Sig. \\
\hline Sikap & .233 & .450 & .000 & 4.304 & .000 \\
Norma Subjektif & -.075 & & & -1.590 & .114 \\
Persepsi Pengendalian Perilaku & .324 & & & 6.004 & .000 \\
& & & & & \\
\hline
\end{tabular}

\section{Pembahasan}

Hasil penelitian menunjukkan besarnya efek dari variabel independen bervariasi. Temuan ini sejalan dengan pernyataan pendapat bahwa anteseden perilaku dapat bervariasi dan bahkan terkadang tidak signifikan, tergantung pada faktor situasional dan kontekstual (Fishbein \& Ajzen, 2011). Riset sebelumnya menyatakan bahwa TPB biasanya menjelaskan 30-45 \% dalam mempengaruhi intensi (Aloulou, 2016). Dalam penelitian ini diperoleh besarnya nilai koefisien TPB 45,0 \% yang menjelaskan intensi berwirausaha. Berdasarkan hasil perhitungan statistik diketahui bahwa H1 diterima, dilihat dari hasil pengujian diperoleh bahwa sikap berpengaruh terhadap intensi berwirausaha. Artinya sikap individual mahasiswa signifikan terhadap intensi berwirausaha. Hal ini didukung oleh penelitian sebelumnya (Cheng \& Chu, 2014; Karimi et al., 2014) menyatakan bahwa terdapat hubungan yang signifikan antara 
sikap dengan intensi berwirausaha, dimana sikap individual yang positif menentukan intensi untuk berwirausaha.

Hal ini menunjukkan bahwa faktor kepercayaan individu mahasiswa pada kemampuan mereka positif dan signifikan mempengaruhi intensi berwirausaha. Berkenaan dengan hasil temuan dalam model, persepsi pengendalian perilaku merupakan prediktor yang paling kuat dalam menentukan intensi berwirausaha. Hal ini sejalan dengan penelitian sebelumnya (Aloulou, 2016; Cheng \& Chu, 2014; Yaghoubi Farani et al., 2017). Ketiganya mengatakan bahwa persepsi pengendalian perilaku sangat terkait erat dengan intensi keberwirausahaan. Pengendalian perilaku yang dirasakan merupakan kondisi dimana individu percaya bahwa suatu tindakan itu mudah atau sulit dilakukan mencakup juga pengalaman di masa lalu. Pengetahuan tentang kewirausahaan yang didapatkan dari pembelajaran sampai pada level magister memberikan bantuan untuk meningkatkan kepercayaan diri dan merasa mampu terlibat dalam perilaku kewirausahaan dan memahami kemampuan pengendalian perilaku tersebut (Liñán et al., 2011; Yaghoubi Farani et al., 2017).

\section{KESIMPULAN}

Dalam studi ini TPB berhasil digunakan untuk menguji niat mahasiswa magister manajemen dalam berwirausaha. Hasil dari pengujian menunjukkan bahwa variabel sikap (attitude) berpengaruh secara signifikan pada intensi berwirausaha. Selain itu PBC atau persepsi pengendalian prilaku sangat signifikan pengaruhnya pada intensi berwirausaha. Namun, terdapat satu prediktor dari TPB yang tidak mempengaruhi intensi berwirausaha dari mahasiswa yaitu norma subjektif. Hal tersebut menunjukkan bahwa dengan kemampuan individu sebagai calon lulusan dari magister manajemen yang mempunyai kemampuan dan pengetahuan yang cukup baik mengenai kewirausahaan membuat individu memiliki kepercayaan diri dalam keputusan karir. Intensi berwirausaha lebih dominan di tentukan oleh diri sendiri melalui kepercayaan individu bukan dipengaruhi oleh orang lain

\section{Keterbatasan dan Agenda Penelitian Mendatang}

Meskipun sudah diupayakan sebaik mungkin, penelitian tentu saja masih memiliki keterbatasan yang dapat digunakan penelitian selanjutnya. Pertama, penelitian ini belum maksimal untuk mengukur intensi berwirausaha mahasiswa yang saat ini telah berada di era internet (online). Tentu penelitian tentang perilaku yang berhubungan dengan kewirausahaan digital memungkinkan untuk di uji pada penelitian selanjutnya. Mengingat cara pendistribusian kuesioner pada penelitian ini adalah dengan menggunakan google formulir, maka keterbatasan kedua yang mungkin adalah pengisian kuesioner yang tidak terkontrol dan berpotensi terjadinya bias, meskipun peneliti mencoba memaksimalkan kemungkinan bias dengan memberikan pertanyaan screening serta mendeskripsikan kriteria-kriteria dari calon responden yang diperbolehkan mengisi kuesioner penelitian ini. Penelitian berikutnya disarankan untuk melakukan pengujian ulang model ini, mendesain pengumpulan data menggunakan metode time-lag untuk meminimalisir common method bias dan memperluas sampel penelitian sehingga hasil penelitian lebih dapat digeneralisasi.

\section{REFERENSI}

Ajzen, I. (1991). The theory of planned behavior. Organizational Behavior and Human Decision Processes. https:// doi.org/ 10.1016/ 0749-5978(91)90020-T 
Al-Jubari, I. (2019). College students' entrepreneurial intention: Testing an integrated model of SDT and TPB. SAGE Open. https:/ / doi.org/ 10.1177/ 2158244019853467

Aloulou, W. J. (2016). Predicting entrepreneurial intentions of final year Saudi university business students by applying the theory of planned behavior. Journal of Small Business and Enterprise Development. https:/ / doi.org/ 10.1108/ JSBED-02-2016-0028 Chen, W., Weng, C. S., \& Hsu, H. (2010). A study of the entrepreneurship of Taiwanese youth by the Chinese Entrepreneur Aptitude Scale. Journal of Technology Management in China. https:/ / doi.org/10.1108/17468771011032778

Cheng, P. Y., \& Chu, M. C. (2014). Behavioral Factors Affecting Students' Intentions to Enroll in Business Ethics Courses: A Comparison of the Theory of Planned Behavior and Social Cognitive Theory Using Self-Identity as a Moderator. Journal of Business Ethics, 124(1), 35-46. https:/ / doi.org/ 10.1007/ s10551-013-1858-0

de Jorge? Moreno, J., Laborda Castillo, L., \& Sanz Triguero, M. (2012). The effect of business and economics education programs on students' entrepreneurial intention. European Journal of Training and Development. https:/ / doi.org/ 10.1108/03090591211220339

Fishbein, M., \& Ajzen, I. (2011). Predicting and changing behavior: The reasoned action approach. In Predicting and Changing Behavior: The Reasoned Action Approach. https:/ / doi.org/ 10.4324/ 9780203838020

Ghozali, I. (2013). Aplikasi Analisis Multivariate Dengan Program IBM dan SPSS 21. In Aplikasi Analisis Multivariate dengan Pogram iIBM SPSS 21. https:/ / doi.org/ 10.1126/ science.1158668

Gorgievski, M. J., Stephan, U., Laguna, M., \& Moriano, J. A. (2018). Predicting Entrepreneurial Career Intentions: Values and the Theory of Planned Behavior. Journal of Career Assessment. https:/ / doi.org/ 10.1177/ 1069072717714541

Hamilton, R. T., \& Harper, D. A. (1994). The Entrepreneur in Theory and Practice. In Journal of Economic Studies. https:/ / doi.org/ 10.1108/01443589410071391

Henley, A., Contreras, F., Espinosa, J. C., \& Barbosa, D. (2017). Entrepreneurial intentions of Colombian business students: Planned behaviour, leadership skills and social capital. International Journal of Entrepreneurial Behaviour and Research. https:/ / doi.org/ 10.1108/ IJEBR-01-2017-0031 Karimi, S., Biemans, H. J. A., Lans, T., Chizari, M., \& Mulder, M. (2014). Effects of role models and gender on students' entrepreneurial intentions. European Journal of Training and Development. https:/ / doi.org/ 10.1108/ EJTD-03-2013-0036

Kotha, R., \& George, G. (2012). Friends, family, or fools: Entrepreneur experience and its implications for equity distribution and resource mobilization. Journal of Business Venturing. https:/ / doi.org/ 10.1016/j.jbusvent.2012.02.001

Krueger, N. F. J., Reilly, M. D., \& Carsrud, A. L. (2000). Competing Models of Entrepreneurial Intentions. Journal of Business Venturing. Journal of Business Venturing2.

Liñán, F., \& Rodríguez-Cohard, J. C. (2015). Assessing the stability of graduates' entrepreneurial intention and exploring its predictive capacity. Academia Revista Latinoamericana de Administracion. https:/ / doi.org/ 10.1108/ ARLA-06-2013-0071

Liñán, F., Urbano, D., \& Guerrero, M. (2011). Regional variations in entrepreneurial cognitions: Start-up intentions of university students in Spain. Entrepreneurship and Regional Development. https:/ / doi.org/ 10.1080/ 08985620903233929

Mohamad, N., Lim, H. E., Yusof, N., \& Soon, J. J. (2015). Estimating the effect of entrepreneur education on graduates' intention to be entrepreneurs. Education and Training. https:/ / doi.org/ 10.1108/ ET-03-2014-0030

Politis, K., Ketikidis, P., Diamantidis, A. D., \& Lazuras, L. (2016). An investigation of social entrepreneurial intentions formation among South-East European postgraduate students. Journal of Small Business and Enterprise Development. https:/ / doi.org/ 10.1108/JSBED-03-2016-0047

Quan, X. (2012). Prior experience, social network, and levels of entrepreneurial intentions. Management Research Review. https:// doi.org/ 10.1108/ 01409171211272679 
Sekaran, U., \& Bougie, R. (2015). Research method for business: A skill building approach, 5th edition. In United States: John Wiley \& Sons Inc.

Shane, S. (2000). Prior Knowledge and the Discovery of Entrepreneurial Opportunities. Organization Science. https:/ / doi.org/ 10.1287/ orsc.11.4.448.14602

Solesvik, M., Westhead, P., \& Matlay, H. (2014). Cultural factors and entrepreneurial intention: The role of entrepreneurship education. Education and Training. https:/ / doi.org/ 10.1108/ ET-07-2014-0075

Solesvik, M. Z. (2013). Entrepreneurial motivations and intentions: Investigating the role of education major. Education and Training, 55(3), 253-271. https:/ / doi.org/ 10.1108/00400911311309314

Sun, H., Lo, C. T., Liang, B., \& Wong, Y. L. B. (2017). The impact of entrepreneurial education on entrepreneurial intention of engineering students in Hong Kong. Management Decision. https:/ / doi.org/ 10.1108/ MD-06-2016-0392

Toft-Kehler, R., Wennberg, K., \& Kim, P. H. (2014). Practice makes perfect: Entrepreneurialexperience curves and venture performance. Journal of Business Venturing. https:/ / doi.org/ 10.1016/j.jbusvent.2013.07.001

Yaghoubi Farani, A., Karimi, S., \& Motaghed, M. (2017). The role of entrepreneurial knowledge as a competence in shaping Iranian students' career intentions to start a new digital business. European Journal of Training and Development. https:/ / doi.org/ 10.1108/ EJTD-07-2016-0054

Yukongdi, V., \& Lopa, N. Z. (2017). Entrepreneurial intention: a study of individual, situational and gender differences. Journal of Small Business and Enterprise Development. https:/ / doi.org/ 10.1108/ JSBED-10-2016-0168

\section{Declarations}

\section{Funding}

The authors received no financial support for the research and publication of this article.

\section{Conflicts of interest/ Competing interests:}

The authors have no conflicts of interest to declare that are relevant to the content of this article.

Data, Materials and/ or Code Availability:

Data sharing is not applicable to this article as no new data were created or analyzed in this study.

\section{Notes on Contributor}

Andi Syaputra adalah dosen tetap Sekolah Tinggi Teknologi Kedirgantaraan (STTKD) Yogyakarta. Minat Penelitian yang digeluti terfokus pada kewirausahaan dan leadership yang merupakan bagian dari ilmu Manajemen Sumber Daya Manusia. Penulis terbuka untuk penelitian bersama (join research) dengan topic sejenis dimasa yang akan datang. Penulis dapat dihubungi melalui email andi.syaputra@sttkd.ac.id.

\section{How to cite this Article}

Syaputra, A. (2021). Menguji Dampak Latar Belakang Pendidikan Pada Intensi Kewirausahaan Mahasiswa Menggunakan Theory of Planned Behavior. Jurnal Manajemen Strategi Dan Aplikasi Bisnis, 4(1), 43 - 52. 